\title{
PSYCHIATRIC HOSPITALIZATIONS DUE TO ALCOHOL AND DRUG consumption among young people in Ceará, Brazil
}

\author{
Alexandre Dido Balbinot ${ }^{1}$
}

\begin{abstract}
Introduction: This study aimed to analyze the evolution of psychiatric hospitalizations among children and adolescents due to psychoactive substance use in the public health system in the state of Ceará, Brazil. Hospitalizations between 2000 and 2015 were used as indicators.
\end{abstract}

Methods: Ecological study using secondary data. Data analysis was performed with the software Stata $11.1^{\circledR}$ from StataCorp LLC (Texas/USA) using Poisson regression with robust variance and Spearman correlation. A 95\% confidence interval was adopted and significance level was set at $5 \%$.

Results: The variables hospitalization rates and mean length of hospital stay did not vary significantly. There was no variation when data were stratified by sex. A negative correlation was found between hospitalization rates and mean length of hospital stay $(P<0.05)$ among girls, but not among boys or overall population.

Conclusion: In Ceará, the creation of alternative mechanisms to hospital admission has not resulted in reduced hospitalization rates.

Keywords: Hospitalization; Ceará (Brazil); mental health; public health system

Psychoactive substance use is a phenomenon observed since the early days of human kind. It is not restricted to one region; it has been part of various cultures around the world over time. One possible reason for this wide dissemination is people's search for pleasure and attempt to minimize suffer. However, the use of these substances is not always healthy, sometimes resulting in health problems and damages to interpersonal relationships ${ }^{1}$.

Historically, people with psychological distress were admitted to psychiatric hospitals, the so-called asylums. Those with problems related to psychoactive substance use had the same treatment. However, with the establishment of the psychiatric reform, alternative services to psychiatric hospital admission were recommended ${ }^{2-4}$.

Current Brazilian legislation prescribes that prevention, treatment, and follow-up in cases of psychoactive substance abuse are provided by an alternative network to hospital admission. Psychosocial Care Centers (CAPS, acronym in Portuguese) were created to meet this purpose, providing the necessary resources for mental health care according to the population size of the region covered by the center ${ }^{5}$.

In cities with more than 100,000 inhabitants, Psychosocial Care Centers for Alcohol and Drugs (CAPS AD) may be implemented with a focus on the issue of drug use. In cities with more than 200,000 inhabitants, Psychosocial Care Centers for Childhood and Adolescence (CAPSi) may be created ${ }^{5}$.

Psychoactive substance abuse has become a relevant public health problem not only in adulthood, but also in early ages. Childhood and adolescence are stages in which subjects are more susceptible to experimentation and consumption of psychoactive substances. It should be noted that in Brazil, in
Clin Biomed Res. 2017;37(1):1-5

1 Centro de Atendimento Educacional Especializado de Cachoeirinha. Cachoeirinha, RS, Brazil.

Corresponding author: Alexandre Dido Balbinot adbalbinot@gmail.com Centro de Atendimento Educaciona Especializado de Cachoeirinha Av. General Anápio Gomes, 321. 9920-170, Cachoeirinha, RS, Brazil. 
addition to illegal substances, selling and providing alcohol and tobacco to children and adolescents is prohibited. Nevertheless, these groups show a high drug use prevalence $\mathrm{e}^{3,6-8}$.

In view of the course of mental health care and the current Brazilian legislation, the present study aimed to analyze the evolution of psychiatric hospitalizations among children and adolescents due to psychoactive substance use in the public health system in the state of Ceará, Brazil. Hospitalizations between 2000 and 2015 were used as indicators.

\section{METHODS}

An ecological design was used in this study to analyze, through secondary data, the evolution of hospitalizations among children and adolescents due to drug use between 2000 and 2015. More specifically, data analysis was based on hospitalization rates and mean length of hospital stay of patients with mental and behavioral disorders due to use of alcohol and other psychoactive substances. Patients of both sexes, aged less than or equal to 19 years, admitted in the state of Ceará were included.

Data were collected from the Health Information System made available by the IT Department of the Brazilian Unified Health System (DATASUS), accessing the link "Informações de saúde" (Health information) > "Epidemiológicas e morbidade" (Epidemiological and morbidity data) > "Morbidade hospitalar do SUS" (Hospital morbidity in SUS). Data on population sizes - required for calculation of hospitalization rates - were collected from the link "Informações de saúde" (Health information) > "Demográficas e socioeconômicas" (Demographical and socioeconomical data) > "Projeção da população das unidades da federação por sexo e grupos de idade: 2000-2013" (Estimated population in federal units by sex and age group: 2000-2013). Data collection was carried out in May 2016.

Then, these data were entered into a Microsoft Excel ${ }^{\circledR}$ spreadsheet. For data analysis, the following dependent variables were defined:

- Hospitalization rates of patients diagnosed with mental and behavioral disorders due to use of alcohol and other psychoactive substances (F10-F19, according to the International Classification of Diseases, ICD);

- Mean length of hospital stay of patients diagnosed with mental and behavioral disorders due to use of alcohol and other psychoactive substances (F10-F19);

- Hospitalization rates were calculated using the following formula: (Number of hospitalizations per cause group per sex in a year) / (Population size per sex in a year) $\times 100,000$ inhabitants.

Data were transferred using the software Stat Transfer $9^{\circledR}$ to the software Stata $11.1^{\circledR}$, in which the statistical analysis was performed. Inferential analysis included the following statistical tests: Poisson regression with robust variance and Spearman correlation. A 95\% confidence interval was adopted and significance level was set at $5 \%$.

\section{RESULTS}

A total of 2,547 hospitalizations of children and adolescents with mental and behavioral disorders due to alcohol and drug use occurred during the period of study were analyzed. Of these, 2,087 (81.94\%) were male and $460(18.06 \%)$ were female.

The overall mean rate was 159,19 (standard deviation, SD: 58.88 ) hospitalizations per year; the lowest number of hospitalizations (41) occurred in 2000 and the highest number (276) in 2008. Male patients showed a mean rate of 130.44 (SD: 47.44) hospitalizations per year; the lowest number of hospitalizations (36) occurred in 2000 and the highest number (214) in 2008. For female patients, the mean hospitalization rate was 28.75 (SD: 14.65); the lowest number of hospitalizations (5) was found in 2000 and the highest number (62) in 2008.

The overall mean rate of hospitalizations $/ 100.000$ inhabitants per year was 0.12 (SD: 0.06 ), with the lowest rate (0.05) recorded in 2000 and the highest rate $(0.23)$ in 2006 . For male patients, a mean rate of 0.14 (SD: 0.05) hospitalizations/100.000 inhabitants per year was found, with the lowest rate $(0.04)$ recorded in 2000 and the highest rate $(0.23)$ in 2008. Female patients showed a mean rate of 0.03 (SD: 0.01 ) hospitalizations/100.000 inhabitants per year, with the lowest rate $(0.01)$ recorded in 2000 and the highest rate (0.06) in 2008.

To better visualize the variation in psychiatric hospitalization rates occurred during the period for both sexes, data are shown using a graphical representation per year of study (figure 1).

The overall mean length of hospital stay was 9.5 days (SD: $2.59 ; 16.8-26.2$ ) per admission. As for each sex, the mean length of stay was 20.17 days (SD: $3.13 ; 16.5-27.9$ ) for male patients and 16.56 days (SD: 6.00; 8.5-27.6) for female patients.

The highest overall mean length of hospital stay (26.2 days per admission) occurred in 2000. Regarding each sex, the highest mean was found in 2000 ( 27.9 days) for male patients and in 2008 (27.6 days) for female patients. The lowest overall mean (16.8 days) occurred in 2010. For male patients, 


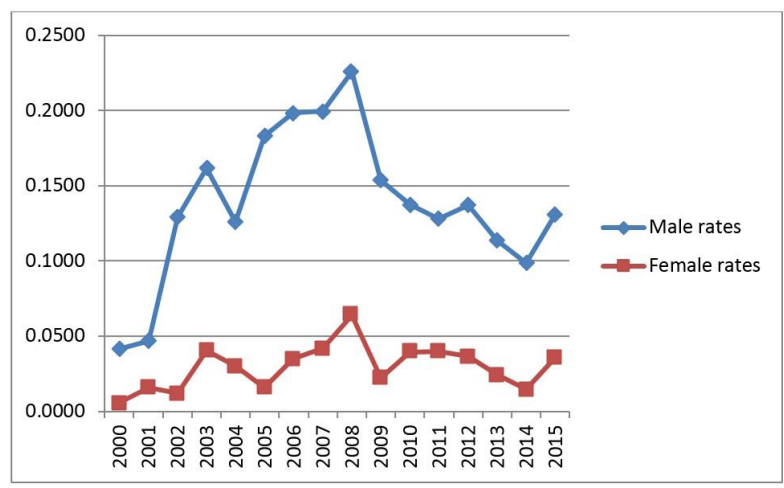

Figure 1: Psychiatric hospitalization rates of children and adolescents with mental and behavioral disorders due to use of alcohol and other psychoactive substances according to sex in the state of Ceará, Brazil, 2000-2015.

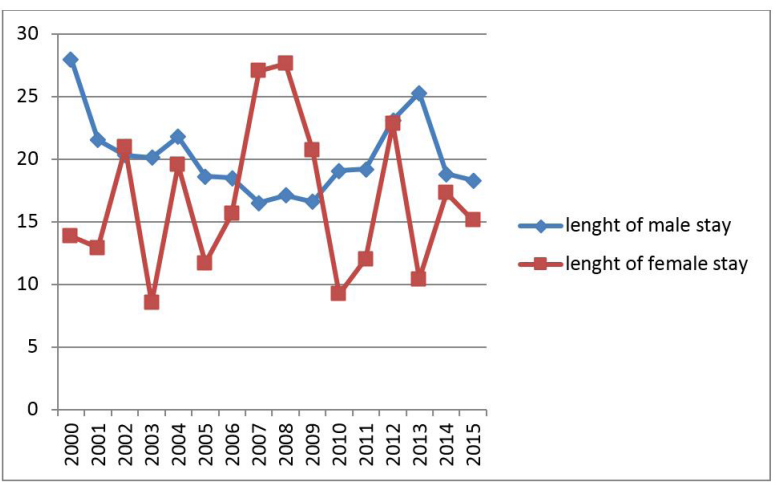

Figure 2: Mean length of hospital stay of children and adolescents with mental and behavioral disorders due to use of alcohol and other psychoactive substances according to sex in the state of Ceará, Brazil, 2000-2015. the lowest mean ( 16.5 days) was found in 2007 and, for female patients, it occurred in 2003 (8.5 days).

Variations in mean length of hospital stay occurred during the period for both sexes are shown using a graphical representation per year of study (figure 2).

Hospitalization rates and mean length of hospital stay did not show significant variation during the period of study. There was no variation when data were stratified by sex as well.

Data from the logistic regression analysis used for evaluation of a possibly significant variation in hospitalization rates and mean length of hospital stay are described in detail in Table 1.

A correlation analysis showed that the higher the hospitalization rate of female patients in a year, the shortest the mean length of hospital stay in the same period $(P<0.05)$. However, this was not true for male patients or the overall population of the study.

Data from the Spearman correlation analysis used for evaluation of a possible correlation between hospitalization rates and mean length of hospital stay are described in detail in Table 2.

\section{DISCUSSION}

There was evidently a greater percentage of hospitalizations of male patients compared to female patients in the period of study. The number was approximately four times higher. This phenomenon may be explained by the epidemiological profile of psychoactive substance consumption among children and adolescents ${ }^{8-10}$.

Table 1: Poisson regression for hospitalization rates and mean length of hospital stay of children and adolescents with mental and behavioral disorders due to use of alcohol and other psychoactive substances according to sex in the state of Ceará, Brazil, 2000-2015.

\begin{tabular}{lcccc}
\hline \multicolumn{1}{c}{ Dependent variable } & Sex & $\begin{array}{c}\text { Regression } \\
\text { coefficient }\end{array}$ & $\mathbf{9 5 \%} \mathbf{C l}$ & $\boldsymbol{P}$-value \\
\hline \multirow{3}{*}{ Hospitalization rate } & Male & 1.01 & $0.97-1.06$ & 0.514 \\
& Female & 1.03 & $0.98-1.08$ & 0.232 \\
& Total & 0.96 & $0.92-1.01$ & 0.145 \\
\hline \multirow{3}{*}{ Mean length of hospital stay } & Male & 0.99 & $0.97-1.01$ & 0.357 \\
& Female & 1.01 & $0.98-1.03$ & 0.796 \\
& Total & 0.99 & $0.98-1.01$ & 0.360 \\
\hline
\end{tabular}

Table 2: Spearman correlation for hospitalization rates and mean length of hospital stay of children and adolescents with mental and behavioral disorders due to use of alcohol and other psychoactive substances according to sex in the state of Ceará, Brazil, 2000-2015.

\begin{tabular}{lccc}
\hline & Sex & $\begin{array}{c}\text { Correlation } \\
\text { coefficient }(\boldsymbol{\rho})\end{array}$ & $\boldsymbol{P}$-value \\
\hline \multirow{3}{*}{ Disorders due to alcohol and other drugs } & Male & 0.092 & 0.736 \\
& Female & -0.729 & $0.001^{*}$ \\
& Total & -0.247 & 0.356 \\
\hline
\end{tabular}

${ }^{*} P<0.05$. 
Similar to the findings of the present study, prevalence studies comparing both sexes showed greater illicit drug consumption in men compared to women. These drugs are usually more likely to cause harm ${ }^{8-10}$.

There was no statistically significant variation in hospitalization rates. This finding shows that the psychiatric reform has been at least partly consolidated in the state of Ceará. This is based on the fact that there was no increase in hospitalization rates; ideally, however, there should be a reduction in hospital admissions to prioritize alternative mechanisms of care delivery. This non-decrease in Ceará is not an exception; on the contrary, a previous study conducted in the state of Rio Grande do Sul found increased hospitalization rates ${ }^{11}$.

These data are consistent with the proposal of containment of a hospital-centered trend observed by the local government and expressed mainly through the State Law n. 12.151/93. However, the stagnation of the construction or contraction of new psychiatric hospital beds does not seem sufficient to reduce drug abuse rates ${ }^{4,12}$. Thus, expanding alternative mechanisms (the CAPS) will contribute to a reduction in hospitalizations due to drug use among children and adolescents.

A decrease in mean length of hospital stay was expected in view of the use of improved tools (drugs or others) providing greater treatment effectiveness. This was not observed within the time frame of the study. Furthermore, a decrease in mean length of hospital stay could lead to higher psychiatric bed turnover and number of hospitalizations. However, there was no change in mean length of stay, so this variable cannot explain the simultaneous maintenance of hospitalization rates.

Conversely, improved therapeutic tools could result in greater treatment effectiveness and, thus, less admissions per patient, minimizing a phenomenon called "revolving door." Reducing the "revolving door" problem would lead to decreased hospitalization rates.

One of the limitations of the present study was the amount and variety of data provided by the census, i.e., this sample did not enable an in-depth analysis of the "revolving door" phenomenon. Nevertheless, this discussion is essential for improving and developing improvement strategies for the available tools.

Differently from what was expected in terms of number of hospitalizations based on the evolution of the epidemiological profile of this age group, especially with the onset of the so-called "crack epidemic," causing harm to human health and to psychosocial aspects, a greater demand for hospital beds was not observed. This may reflect the epidemiological situation in the state of Ceará, where, according to a survey conducted between 2004 and 2010 with children (10-12 years) and adolescents (16-18 years), there was no change in drug use prevalence over this period of six years. The age group 13-15 years showed a $7 \%$ reduction in drug use, which is similar to the number found in a survey conducted between 2001 and 2005 with a general population ${ }^{10}$. This percentage was also found in a 2004 survey with students of both sexes comparing data from $1997^{9}$.

Thus, the evolution of psychiatric hospitalizations due to psychoactive substance use/abuse among children and adolescents in the state of Ceará, where there was no change in hospitalization rates and length of hospital stay, seems to be related mainly to the epidemiological profile of the population and to a restriction on contraction of new psychiatric beds. Moreover, the creation of alternative mechanisms to hospital admission has not resulted in reduced hospitalization rates, i.e., these services have not solved the problem.

The effectiveness of the treatment for alcohol and drug abuse/dependence outside a hospital environment is often affected by a difficulty in keeping the person under control, with no access to psychoactive substances. At the beginning of treatment, when a nerve-wracking feeling is stronger, hospital admissions facilitate and ensure the creation and maintenance of a minimum period of abstinence in order to address important aspects of patients and their contexts, as well as to develop strategies to stay abstinent. This may be the reason why hospital admissions continue to be used and sought by the social actors involved in the issue of child and adolescent treatment.

\section{CONCLUSIONS}

Revising public policies and investments in mental health is still necessary. In the state of Ceará, there seems to be a need to break the paradigms of child and adolescent care related to drug addiction, strengthening alternative services in place of psychiatric hospitalizations. The consolidation of therapeutic tools used during hospital admission that may be adopted by patients after discharge is also important, with the aim of providing effective care and preventing the "revolving door" phenomenon. 


\section{REFERENCES}

1. Pratta EM, Santos MA. O processo saúde-doença e a dependência química: interfaces e evolução. Psicol, Teor Pesqui. 2009;25:203-11.

2. Tenório F. A reforma psiquiátrica brasileira, da década de 1980 aos dias atuais: história e conceitos. Hist Cienc Saúde Manguinhos. 2002;9:25-59.

3. Brasil. Lei n. 10.216, de 6 de abril de 2001. Dispõe sobre a proteção e os direitos das pessoas portadoras de transtornos mentais e redireciona o modelo assistencial em saúde mental. Diário Oficial da União. 1990 Abr 9. [cited 2016 Aug 17]. Available from: http://www.planalto.gov.br/ccivil_03/ leis/leis_2001/l10216.htm

4. Brasil. Lei n. 12.151, de 29 de julho de 1993. Dispõe sobre a extinção progressiva dos hospitais psiquiátricos e sua substituição por outros recursos assistenciais, regulamenta a internação psiquiátrica compulsória, e dá outras providências. Diário Oficial da União. 1993. [cited 2016 Aug 17]. Available from: http://www.planalto. gov.br/ccivil_03/_Ato2007-2010/2009/ Lei/L12151.htm

5. Brasil. Ministério da Saúde. Saúde mental no SUS: os centros de atenção psicossocial. Brasília; 2004.
6. Lopes AP, Rezende MM. Consumo de substâncias psicoativas em estudantes do ensino médio. Psicol Teor Prat. 2014;16:29-40.

7. Brasil. Presidência da República. Subsecretaria para Assuntos Jurídicos. Estatuto da Criança e do Adolescente. Brasília; 1990. [cited 2016 Aug 17]. Available from: http:// www.planalto.gov.br/ccivil_03/leis/ L8069.htm

8. Carlini EA, Noto AR, Sanchez ZV, Carlini CM, Locatelli DP, Abeid $\mathrm{LR}$, et al. VI levantamento nacional sobre o consumo de drogas psicotrópicas entre estudantes do ensino fundamental e médio das redes pública e privada de ensino nas 27 capitais brasileiras: 2010 . Brasília: SENAD; 2010. [cited 2016 Aug 17]. Available from: http://www.antidrogas. com.br/downloads/vi_levantamento. pdf

9. Carlini EA. V levantamento nacional sobre o consumo de drogas psicotrópicas entre estudantes do ensino fundamental e médio da rede pública de ensino nas 27 capitais brasileiras: 2004. Brasília: UNIFESP, Centro Brasileiro de informações sobre Drogas Psicotrópicas; 2005. [cited 2016 Aug 17]. [cited 2016 Aug 17]. Available from: http://www. cebrid.epm.br/levantamento_brasil2/ pp001a010.pdf

10. Carlini EA, Galduróz JCF, Noto AR, Fonseca AM, Carlini CM, Oliveira LG, et al. II levantamento domiciliar sobre uso de drogas Psicotrópicas no Brasil: estudo envolvendo as 108 maiores cidades do país: 2005. Brasília: Secretaria Nacional Antidrogas; São Paulo: Centro Brasileiro de Informações sobre Drogas Psicotrópicas, Universidade Federal de São Paulo; 2007.

11. Balbinot $A D$, Haubert $A$, Teixeira MB. Hospitalizações de crianças e adolescentes por uso de substâncias psicoativas no Rio Grande do Sul entre 2000 e 2012. In: Anais da Mostra de Iniciação Científica do CESUCA; 2014; Cachoeirinha. Cachoeirinha: CESUCA; 2014. [cited 2016 Aug 17]. Available from: http:// ojs.cesuca.edu.br/index.php/mostrac/ article/viewFile/750/pdf_107

12. Pontes PA, Fraga MN. Reforma psiquiátrica no Ceará: descrição de um caso. Rev Lat Am Enfermagem. 1997;5:45-50. 